\title{
ALDOSTERONE EXCRETION IN VIRILIZING ADRENAL HYPERPLASIA *
}

\author{
By ROBERT M. BLIZZARD, GRANT W. LIDDLE, CLAUDE J. MIGEON AND \\ LAWSON WILKINS \\ (From the Department of Pediatrics and Division of Endocrinology, The Ohio State University, \\ Columbus, Ohio; Department of Medicine, Vanderbilt University, Nashville, Tenn.; \\ and Department of Pediatrics, Johns Hopkins Hospital, Baltimore, Md.)
}

(Submitted for publication January 19, 1959; accepted April 23, 1959)

Sodium depletion with concomitant dehydration occurs as a complicating factor in approximately one-third of patients with virilizing adrenal hyperplasia (1). A number of writers have discussed certain differences between the electrolyte disturbance occurring in this syndrome and that of Addison's disease (2-5) and several hypotheses have been offered to explain the sodium loss and potassium retention which occur $(1,4,6,7)$. Although the role of aldosterone is pertinent in many of these hypotheses, the only reported study of aldosterone excretion in patients with virilizing adrenal hyperplasia is that of Prader, Spahr and Neher (6).

In order further to elucidate aldosterone metabolism in this syndrome the present studies were undertaken utilizing subjects both with and without defects of sodium regulation. Accumulated data indicate that patients with virilizing adrenal hyperplasia without associated salt loss excrete normal, or high levels of aldosterone on an ad lib. salt intake, and respond with significant increases in aldosterone excretion when placed on limited sodium diets. In contrast, patients with salt loss probably excrete deficient quantities of aldosterone as compared to the normal individual, and are unable to respond with significant increases in aldosterone excretion when sodium intake is limited. Ancillary studies compare the ability of normal infants and adults to excrete aldosterone, both with ingestion of a normal and a sodium deficient diet.

\section{METHODS}

Daily 24 hour collections of urine were preserved with refrigeration and thymol. Occasionally two or three

* This investigation was supported by research grants (A-180; A-1917 G. M.; A. H. 1784) from the Institute of Arthritis and Metabolic Diseases, National Institutes of Health, United States Public Health Service. day specimens from infants were pooled. In preparation for assay the urine was acidified to $\mathrm{pH} 1.0$ and allowed to stand at room temperature for 24 hours. The "free" steroids were then extracted with dichloromethane. The extracts were washed with aqueous sodium carbonate, dehydrated with sodium sulfate, and evaporated to dryness under a stream of nitrogen. The residues were redissolved in ethanol. These crude extracts were either: 1 ) injected into adrenalectomized dogs for assays of aldosterone content by the method of Liddle, Cornfield, Casper and Bartter ( 8$)$; 2) subjected to multiple systems of paper chromatography following which the aldosterone fraction was assayed by the same method; or 3) fractionated and assayed for aldosterone content by the isotope-derivative method of Kliman and Peterson (9). The three methods yielded comparable results when run in parallel on the same urine specimens (Table I). Assays carried out only in adrenalectomized dogs were subject to the limitation of relative lack of sensitivity of this method, i.e., a minimum dose of $1 \mu \mathrm{g}$. of aldosterone (per assay animal) was required to induce a distinct response. As a rule an attempt was made to assay each specimen in at least three or four animals. As a result, unless a specimen contained a total of at least 3 or $4 \mu \mathrm{g}$. of aldosterone, the responses would be negligible. Under such circumstances it was possible to say only that the amount of aldosterone was "less than" a certain value. In such instances (indicated in the tables and graphs by the symbol $<$ or $\downarrow$ ) the specimen might have contained no aldosterone whatever. This limitation did not apply to the isotope derivative method.

During dietary control periods salt was permitted freely according to each individual's habits. During periods of salt restriction, sodium intake was limited to $9 \mathrm{mEq}$. or less per day in older patients, and $1 \mathrm{mEq}$. or less in infants. The sodium free diet for infants consisted of a commercially available low sodium formula, 1 containing $1 \mathrm{mEq}$. of sodium per L. Although it was necessary to administer sodium chloride to infants with the salt losing form of adrenal hyperplasia in quantities of 45 to 120 $\mathrm{mEq}$. per day in order to maintain life, these patients never were completely hydrated during the collection periods, and were continually bordering on, or were in, adrenal crisis.

Serum sodium and potassium and urinary sodium were

1 Lonalac®, Mead Johnson and Co. 
determined using a flame photometer with a lithium internal standard. Plasma volume was measured using $\mathrm{I}^{131}$ tagged albumin (10). Glomerular filtration rate was calculated using endogenous creatinine clearance as initially applied by Miller and Winkler (11).

\section{RESULTS AND COMMENTS}

Most previous investigators studing the physiology of aldosterone have studied only adult patients. It became apparent in the course of the present study that aldosterone excretion is a function of age, and that it was misleading to compare the urinary aldosterone levels of abnormal infants with those of adults, whether normal or abnormal. Table II, therefore, lists the data of aldosterone excretion in seven normal children between the ages of one week and three and onehalf years, and in 16 normal adults. Table III similarly lists aldosterone excretion of 16 patients with the non-salt losing form of congenital adrenal hyperplasia, and Table IV, that of $11 \mathrm{pa}-$

TABLE I

Comparison of urinary aldosterone assay results by different methods*

\begin{tabular}{|c|c|c|c|}
\hline \multirow[b]{2}{*}{ Specimen } & \multicolumn{2}{|c|}{ Dog bioassay } & \multirow{2}{*}{$\begin{array}{l}\text { Isotope } \\
\text { derivative } \\
\text { assay }\end{array}$} \\
\hline & $\begin{array}{l}\text { Crude } \\
\text { extract }\end{array}$ & $\begin{array}{c}\text { Chromatographed } \\
\text { extract }\end{array}$ & \\
\hline
\end{tabular}

Normal individuals

$\begin{array}{rrr}1 & <2 & 1 \\ 2 & 4 & 5 \\ 3 & 12 & 10 \\ 4 & 3 & 5\end{array}$

Non-salt losers

$\begin{array}{rrr}1 & <6 & \\ 2 & <12 & 8 \\ 3 & 5 & 5 \\ 4 & 6 & 8 \\ 5 & 16 & 11 \\ 6 & 7 & 7 \\ 7 & 11 & 4 \\ 8 & 10 & 19\end{array}$

Salt losers

$\begin{array}{rrrr}1 & 2 & & 1 \\ 2 & 8 & & 4 \\ 3 & 9 & & 5 \\ 4 & 2 & & 4 \\ 5 & 4 & & 2 \\ 6 & <1 & & \\ 7 & <1 & 2 & \\ 8 & 2 & 3 & \\ 9 & 4 & 6 & \\ 10 & <1 & <4 & \\ 11 & <4 & & \end{array}$

* All results are expressed in micrograms per 24 hours. tients with the same syndrome but with associated salt loss.

Since in normal infants the urinary excretion of aldosterone and the response to sodium deprivation is apparently less than in older children and adults, it is necessary to consider the findings in the patients with the salt losing and non-salt losing types of virilizing adrenal hyperplasia in relation to their age groups.

I. Aldosterone excretion in normal control subjects (Table II)

A. Adults. Fourteen of 16 adults studied during an ad lib. salt intake excreted between 3 and $8 \mu \mathrm{g}$. of aldosterone per 24 hours. One patient (C.Y.) excreted $1 \mu \mathrm{g}$., and one patient (A.R.) 9 $\mu \mathrm{g}$. We have, therefore, regarded the normal adult excretion value under these circumstances to be 3 to $8 \mu \mathrm{g}$. per 24 hours. With sodium restriction to $9 \mathrm{mEq}$. or less per day, aldosterone excretion increased to between 20 and $66 \mu \mathrm{g}$. per day.

$B$. Infants. Four infants, less than two months of age, were studied and three were subjected to a low sodium diet. Aldosterone excretion during the control period was probably less than the 3 to 8

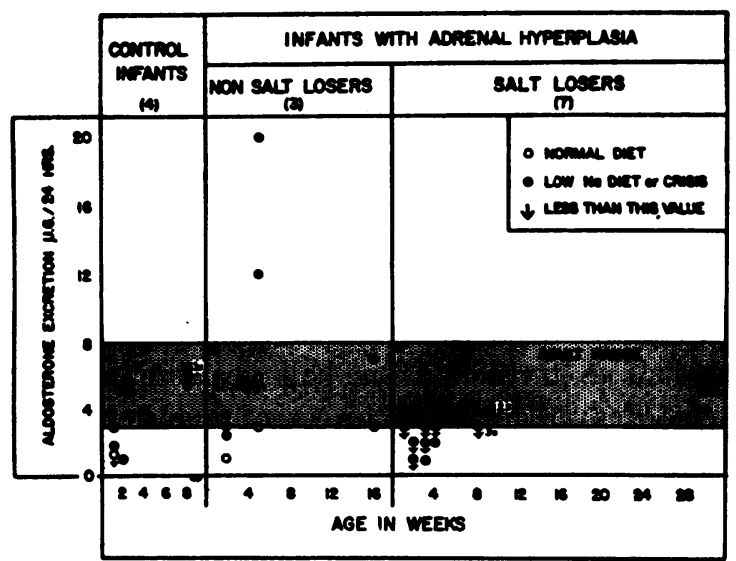

Fig. 1. Aldosterone Excretion in Normal Infants and Infants with Virilizing Adrenal Hyperplasia

The shaded area represents the normal adult range of aldosterone excretion when adults are on ad lib. salt intakes. Since both on a low salt diet and during a spontaneous adrenal crisis the intravascular volume is decreased, and since this is a known stimulus to aldosterone production (18), these two stress situations are assumed to be comparable (see key, $\bullet$ ). 
TABLE II

Aldosterone excretion in normal adults (A1-16), normal infants (B17-20) and normal older children (C21-23)*

\begin{tabular}{|c|c|c|c|c|c|c|c|c|c|c|c|}
\hline \multirow[b]{3}{*}{ Patient } & \multirow[b]{3}{*}{ Age } & \multirow[b]{3}{*}{$\mathbf{R x}$} & \multicolumn{7}{|c|}{ Aldosterone (ug./24 hours) } & \multirow{3}{*}{$\begin{array}{l}\text { Aldosterone } \\
\text { method }\end{array}$} & \multirow[b]{3}{*}{ Comment } \\
\hline & & & \multicolumn{7}{|c|}{ Day of low sodium diet } & & \\
\hline & & & Control & 1 & 2 & 3 & 4 & 5 & 6 & & \\
\hline $\begin{aligned} \text { A-1 } & \text { E.L. } \\
2 & \text { W.D. } \\
3 & \text { C.Y. } \\
4 & \text { A.R. } \\
5 & \text { E.M. } \\
6 & \text { V.B. } \\
7 & \text { R.F. } \\
8 & \text { H.W. } \\
9 & \text { R.K. } \\
10 & \text { J.J. } \\
11 & \text { W.M. } \\
12 & \text { D.D. } \\
13 & \text { M.B. } \\
14 & \text { Y.N. } \\
15 & \text { I.C. } \\
16 & \text { H.M. }\end{aligned}$ & $\begin{array}{l}18 \text { years } \\
18 \text { years } \\
18 \text { years } \\
19 \text { years } \\
19 \text { years } \\
19 \text { years } \\
20 \text { years } \\
22 \text { years } \\
24 \text { years } \\
25 \text { years } \\
25 \text { years } \\
27 \text { years } \\
32 \text { years } \\
47 \text { years } \\
48 \text { years } \\
73 \text { years }\end{array}$ & $\begin{array}{l}0 \\
0 \\
0 \\
0 \\
0 \\
0 \\
0 \\
0 \\
0 \\
0 \\
0 \\
0 \\
0 \\
0 \\
0 \\
0\end{array}$ & $\begin{array}{l}4 \\
5 \\
1 \\
9 \\
6 \\
7 \\
5 \\
4 \\
4 \\
3 \\
6 \\
8 \\
6 \\
8 \\
4 \\
3\end{array}$ & $\begin{array}{r}2 \\
6 \\
10 \\
12 \\
6 \\
6 \\
4 \\
4 \\
7 \\
3 \\
6 \\
9 \\
7 \\
10 \\
4 \\
3\end{array}$ & $\begin{array}{r}6 \\
8 \\
9 \\
10 \\
8 \\
10 \\
4 \\
6 \\
7 \\
5 \\
8 \\
11 \\
12 \\
15 \\
7 \\
4\end{array}$ & $\begin{array}{r}9 \\
12 \\
16 \\
16 \\
12 \\
19 \\
5 \\
5 \\
14 \\
8 \\
12 \\
20 \\
15 \\
20 \\
10 \\
9\end{array}$ & $\begin{array}{r}19 \\
20 \\
28 \\
28 \\
16 \\
27 \\
11 \\
9 \\
16 \\
13 \\
19 \\
30 \\
23 \\
32 \\
12 \\
15\end{array}$ & $\begin{array}{r}15 \\
40 \\
37 \\
38 \\
23 \\
32 \\
13 \\
19 \\
36 \\
20 \\
27 \\
29 \\
33 \\
35 \\
13 \\
7\end{array}$ & $\begin{array}{l}66 \\
38 \\
32 \\
22 \\
39 \\
47 \\
21 \\
25 \\
34 \\
34 \\
34 \\
52 \\
30 \\
20 \\
20\end{array}$ & $\begin{array}{l}\text { D.A.-C.E. } \\
\text { D.A.-C.E. } \\
\text { D.A.-C.E. } \\
\text { D.A.-C.E. } \\
\text { D.A.-C.E. } \\
\text { D.A.-C.E. } \\
\text { D.A.-C.E. } \\
\text { D.A.-C.E. } \\
\text { D.A.-C.E. } \\
\text { D.A.-C.E. } \\
\text { D.A.-C.E. } \\
\text { D.A.-C.E. } \\
\text { D.A.-C.E. } \\
\text { D.A.-C.E. } \\
\text { D.A.-C.E. } \\
\text { D.A.-C.E. }\end{array}$ & \\
\hline B-17 D.O. & 1 week & 0 & $<2$ & & & 3 & 2 & & & D.A.-C.E. & $\begin{array}{l}\text { Urinary } \mathrm{Na}, 3 \mathrm{mEq} \text {. } 4 \text { th day } \\
\text { Serum electrolytes, normal }\end{array}$ \\
\hline 18 D.F. & 2 weeks & 0 & $<6$ & & & & 1 & $<6$ & & D.A.-C.E. & $\begin{array}{l}\text { Urinary } \mathrm{Na}, 3 \mathrm{mEq} \text {. } 5 \text { th day } \\
\text { Body wt., } 2,130-1,970 \mathrm{Gm} \text {. } \\
5 \text { th day }\end{array}$ \\
\hline $\begin{array}{l}19 \text { C.P. } \\
20 \text { C.C. }\end{array}$ & $\begin{array}{l}4 \text { weeks } \\
8 \text { weeks }\end{array}$ & $\begin{array}{l}\mathbf{0} \\
\mathbf{0}\end{array}$ & $\begin{array}{r}4 \\
<6\end{array}$ & & & & 6 & 6 & 6 & $\begin{array}{l}\text { D.A.-C.E. } \\
\text { D.A.-C.E. }\end{array}$ & $\begin{array}{l}\text { Urinary } \mathrm{Na}, 2.0 \mathrm{mEq} .5 \mathrm{th} \text { day } \\
\text { Serum electrolytes, normal }\end{array}$ \\
\hline C-21 J.E. & 2.5 yrs. & $\mathbf{0}$ & 2 & & & & $\begin{array}{l}6 \\
4\end{array}$ & & 7 & $\begin{array}{l}\text { D.A.-C.E. } \\
\text { I.D. }\end{array}$ & \\
\hline 22 L.C. & 3 years & 0 & $<2$ & & & & & $\begin{array}{l}4 \\
6\end{array}$ & & $\begin{array}{l}\text { D.A.-C.E. } \\
\text { I.D. }\end{array}$ & \\
\hline 23 L.N. & 3.5 yrs. & 0 & $\begin{array}{l}3 \\
2\end{array}$ & & & & 12 & $\begin{array}{l}10 \\
12\end{array}$ & & $\begin{array}{l}\text { D.A.-C.E. } \\
\text { I.D. }\end{array}$ & \\
\hline
\end{tabular}

* Control values were obtained while the individuals were maintained on an unrestricted sodium diet. During the periods of salt restriction sodium intake was limited to $9 \mathrm{mEq}$. or less per day for Groups $\mathrm{A}$ and $\mathrm{C}$ and less than $1 \mathrm{mEq}$. for Group B. The following symbols are used: D.A., dog assay; C.E., crude extract; I.D., isotope derivative assay.

$\mu \mathrm{g}$. excreted by adults under similar circumstances. With salt deprivation aldosterone excretion did not rise above the adult control level (Figure 1).

C. Older children. Three children, two and one-half to three and one-half years of age, excreted less than adult levels of aldosterone on regular diets, but output rose to levels of 6 to 12 $\mu \mathrm{g}$. per day during sodium restriction.

II. Aldosterone excretion in infants with non-salt losing, virilizing adrenal hyperplasia (Table III, $A$ )

Three children (D.K., B.S., L.S.), 16 weeks of age or younger, were subjected to a low salt diet. At this time cortisone therapy had not been initiated. In two of the three patients aldosterone excretion significantly increased during salt de- privation (Figure 1). One infant (B.S.) six weeks of age, excreted $20 \mu \mathrm{g}$. of aldosterone on the fifth day of sodium deprivation, responding quantitatively as would an adult. None of the infants manifested clinical dehydration or serum electrolyte alterations.

\section{Aldosterone excretion in infants with salt} losing, virilizing adrenal hyperplasia (Table IV)

Seven infants who had not been previously treated, and who were admitted to the hospital in, or bordering on, salt losing crisis were studied. Salt retaining steroids and cortisone were not used therapeutically prior to or during the initial study. One patient (S.M.) was subsequently restudied while receiving cortisone. Although salt administration in limited amounts was necessary to maintain life, the urine collections were made 
while the patients were still dehydrated, and often hyponatremic and hyperkalemic.

Nineteen determinations for aldosterone were performed on 15 urines of these seven patients who were 30 weeks or less of age. In two instances the aldosterone values were $4 \mu \mathrm{g}$. per 24 hours. The remainder of the determinations were less than this value. In some cases it was only possible to state that the urine contained less than the designated value because of the limitations of the dog assay method (Figure 1). It is possible that there may have been no aldosterone in these samples.

\section{Aldosterone excretion in older children and} adults with non-salt losing, virilizing adrenal hyperplasia (Table III)

Aldosterone excretion was measured in 13 patients between four and three-fourths and 32 years of age who had never had symptoms of salt loss. Of 19 determinations in this age group obtained while these patients were receiving normal sodium intakes, 14 were above the adult range of 3 to 8 $\mu \mathrm{g}$. per day and five were within this range (Table III, Figure 2). Four of the patients were receiving cortisone therapy at the time the studies were

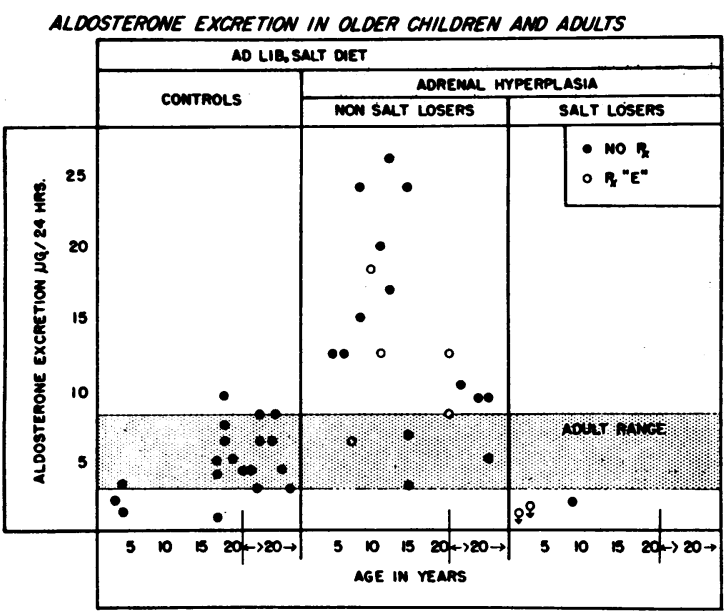

Fig. 2. Aldosterone Excretion of 19 Control Subjects Between Two and One-Half and 73 Years of Age, 13 Individuals Having Non-Salt Losing, Virilizing Adrenal Hyperplasia Between Four and ThreeFourths and 32 Years of Age, and Three Older Children Between One and Three-Fourths and Nine Years of Age Having Previously Had Salt losing Symptoms with Virilizing Adrenal Hyperplasia

None of the last group had required salt retaining steroids for at least one year. All subjects were on an unrestricted sodium intake. The shaded area represents the normal adult range of aldosterone excretion when adults are on an $a d$ lib. salt intake.

TABLE III

Aldosterone excretion in infants (A1-3), older children and adults (B4-16) with non-salt losing, virilizing adrenal hyperplasia*

\begin{tabular}{|c|c|c|c|c|c|c|c|c|c|}
\hline \multirow[b]{3}{*}{ Patient } & \multirow[b]{3}{*}{ Age } & \multirow[b]{3}{*}{$\mathbf{R x}$} & \multicolumn{6}{|c|}{ Aldosterone (ug./24 hours) } & \multirow{3}{*}{$\begin{array}{c}\text { Aldosterone } \\
\text { method }\end{array}$} \\
\hline & & & \multicolumn{6}{|c|}{ Day of low sodium diet } & \\
\hline & & & Control & 1 & 2 & 3 & 4 & 5 & \\
\hline A-1 D.K. & 1 week & 0 & 1 & & & 4 & 3 & $\begin{array}{r}3 \\
<6\end{array}$ & I.D. \\
\hline 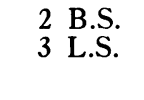 & $\begin{array}{r}5 \text { weeks } \\
16 \text { weeks }\end{array}$ & $\begin{array}{l}0 \\
0\end{array}$ & $3, \underset{3}{<6}$ & & & & 12 & $\begin{array}{r}20 \\
7 \\
<12\end{array}$ & $\begin{array}{l}\text { D.A.-C.E. } \\
\text { I.D. } \\
\text { D.A.-C.E. }\end{array}$ \\
\hline $\begin{aligned} \text { B-4 } & \text { C.W. } \\
5 & \text { C.A. } \\
6 & \text { H.T. } \\
7 & \text { A.B. } \\
8 & \text { J.D. } \\
9 & \text { C.L. } \\
10 & \text { T.T. } \\
11 & \text { D.B. } \\
12 & \text { C.L. } \\
13 & \text { N.K. } \\
14 & \text { E.H. } \\
15 & \text { J.L. } \\
16 & \text { M.H. }\end{aligned}$ & $\begin{array}{r}4 \text { years } \\
6 \text { years } \\
7 \text { years } \\
8 \text { years } \\
10 \text { years } \\
11 \text { years } \\
11 \text { years } \\
13 \text { years } \\
16 \text { years } \\
16 \text { years } \\
25 \text { years } \\
25 \text { years } \\
32 \text { years }\end{array}$ & $\begin{array}{c}0 \\
0 \\
\text { "E", } \\
0 \\
\text { "E", } \\
\text { "E" } \mathrm{E}, \\
0 \\
0 \\
0 \\
0 \\
\text { "E" } \\
0 \\
0\end{array}$ & $\begin{array}{c}12 \\
12 \\
6 \\
24,15 \\
18 \\
12 \\
20 \\
26,17 \\
6,3 \\
24 \\
12,8 \\
10 \\
9,9,5\end{array}$ & & & 12 & $\begin{array}{l}41 \\
10 \\
\\
18\end{array}$ & 36 & $\begin{array}{l}\text { D.A.-C.E. } \\
\text { D.A.-C.E. } \\
\text { D.A.-C.E. } \\
\text { D.A.-C.E. } \\
\text { D.A.-C.E. } \\
\text { D.A.-C.E. } \\
\text { D.A.-C.E. } \\
\text { D.A.-C.E. } \\
\text { D.A.-C.E. } \\
\text { D.A.-C.E. } \\
\text { D.A.-C.E. } \\
\text { D.A.-C.E. } \\
\text { D.A.-C.E. }\end{array}$ \\
\hline
\end{tabular}

* During the periods of salt restriction sodium intake was limited to less than $1 \mathrm{mEq}$. per day for Group A and less than $9 \mathrm{mEq}$. per day for Group B. The following symbols are used: "E", cortisone (25 to $37.5 \mathrm{mg}$. per day); D.A., dog assay; C.E., crude extract ; I.D. isotope derivative assay. 
TABLE IV

Aldosterone excretion in infants with salt losing, virilizing adrenal hyperplasia (A 1-7) and older children who had previously had salt losing symptoms with virilizing adrenal hyperplasia, but who had required no salt retaining steroid for at least one year $(B 8-11)^{*}$

\begin{tabular}{|c|c|c|c|c|c|c|c|c|c|c|c|c|}
\hline \multirow[b]{3}{*}{ Patient } & \multirow[b]{3}{*}{ Age } & \multirow[b]{3}{*}{$\mathbf{R x}$} & \multicolumn{6}{|c|}{ Aldosterone ( $\mu$ g./24 hours) } & \multirow{3}{*}{$\begin{array}{c}\text { Spontaneous } \\
\text { crisis }\end{array}$} & \multirow{3}{*}{$\begin{array}{l}\text { Aldosterone } \\
\text { method }\end{array}$} & \multirow{3}{*}{\multicolumn{2}{|c|}{ Comment }} \\
\hline & & & \multicolumn{6}{|c|}{ Day of low sodium diet or crisis } & & & & \\
\hline & & & Control & & 2 & 3 & 4 & 5 & & & & \\
\hline \multirow[t]{2}{*}{ A-1 E.S. $\dagger$} & \multirow[t]{2}{*}{1 week } & \multirow[t]{2}{*}{0} & & & & & & & $4,<3$ & D.A.-C.E. & \multirow{2}{*}{\multicolumn{2}{|c|}{$\begin{array}{l}\text { Serum } \mathrm{Na}, 134-139 \mathrm{mEq} \text {. } \\
\text { Serum } \mathrm{K}, 6.3-8.2 \mathrm{mEq} \text {. } \\
\text { Severe dehydration }\end{array}$}} \\
\hline & & & & & & & & & $<4,<1$ & D.A.-Ch.E. & & \\
\hline 2 B.H. & 2 weeks & 0 & & & & & & & $<1,<2$ & D.A.-C.E. & \multicolumn{2}{|c|}{$\begin{array}{l}\text { Serum } \mathrm{Na}, 122-131 \mathrm{mEq} . \\
\text { Serum } \mathrm{K}, 5.4-6.0 \mathrm{mEq} \text {. } \\
\text { Moderate dehydration }\end{array}$} \\
\hline $3 \mathrm{~J} . \mathrm{J}$. & 2.5 weeks & 0 & & & & & & & $<2$ & D.A.-C.E. & \multicolumn{2}{|c|}{$\begin{array}{l}\text { Serum } \mathrm{Na}, 131-143 \mathrm{mEq} . \\
\text { Serum } \mathrm{K}, 9.8 \mathrm{mEq} \text {. } \\
\text { Moderate dehydration }\end{array}$} \\
\hline \multirow[t]{2}{*}{4 K.S. } & \multirow[t]{2}{*}{2.5 weeks } & \multirow[t]{2}{*}{0} & & & & & & & $1,<3$ & D.A.-C.E. & \multirow{2}{*}{\multicolumn{2}{|c|}{$\begin{array}{l}\text { Serum } \mathrm{Na}, 130-138 \mathrm{mEq} . \\
\text { Serum K, } 6.5 \mathrm{mEq} . \\
\text { Severe dehydration }\end{array}$}} \\
\hline & & & & & & & & & $<1$ & D.A.-Ch.E. & & \\
\hline \multirow[t]{2}{*}{5 D.H. } & \multirow[t]{2}{*}{4 weeks } & \multirow[t]{2}{*}{0} & & & & & & & $2,<3$ & D.A.-C.E. & \multirow{2}{*}{\multicolumn{2}{|c|}{$\begin{array}{l}\text { Serum Na, } 143-159 \mathrm{mEq} \text {. } \\
\text { Serum K, 5.9-6.3 mEq. } \\
\text { Severe dehydration }\end{array}$}} \\
\hline & & & & & & & & & 2 & D.A.-Ch.E. & & \\
\hline \multirow[t]{2}{*}{6 S.M. } & 8 weeks & $\mathbf{0}$ & & & & & & & $<3,(3 \times)$ & D.A.-C.E. & \multicolumn{2}{|c|}{$\begin{array}{l}\text { Serum Na, } 117-126 \mathrm{mEq} . \\
\text { Serum K, } 6.5-7.6 \mathrm{mEq} . \\
\text { Moderate dehydration }\end{array}$} \\
\hline & 9 weeks & $\begin{array}{l}15 \mathrm{mg} . \\
\text { E/os } \\
\text { q.d. }\end{array}$ & & & & & & & $<4,(2 \times)$ & D.A.-C.E. & \multicolumn{2}{|l|}{$\begin{array}{l}\text { Serum } \mathrm{Na}, 135 \mathrm{mEq} . \\
\text { Serum } \mathrm{K}, 8.6 \mathrm{mEq} . \\
\text { Moderate dehydration }\end{array}$} \\
\hline 7 J.A. & 30 weeks & 0 & & & & & & & 4 & D.A.-C.E. & \multicolumn{2}{|l|}{$\begin{array}{l}\text { Serum } \mathrm{Na}, 130 \mathrm{mEq} . \\
\text { Serum } \mathrm{K}, 6.2 \mathrm{mEq} . \\
\text { Moderate dehydration }\end{array}$} \\
\hline B-8 S.W. & $19 / 12$ & "E" & 1 & & $1 \ddagger$ & & & & & D.A.-C.E. & Control day & Crisis day $\ddagger$ \\
\hline & & & & & $<1$ & & & & & D.A.-Ch.E. & $\begin{array}{l}\text { Serum Na, } 138 \mathrm{mEq} . \\
\text { Serum K, } 5.7 \mathrm{mEq} . \\
\text { Body wt., } 9,930 \mathrm{Gm} \text {. } \\
\text { Urinary Na, } 166 \\
\text { mEq. } \\
\text { Dehydration-none }\end{array}$ & $\begin{array}{l}124 \mathrm{mEq} \\
7.2 \mathrm{mEq} \text {. } \\
9,300 \mathrm{mg} \text {. } \\
22 \mathrm{mEq} . \\
\text { Severe }\end{array}$ \\
\hline 1 E.S.† & $\begin{array}{l}21 / 2 \\
\text { years }\end{array}$ & “E” & & & & & & & 1 & D.A.-C.E. & $\begin{array}{l}\text { Serum } \mathrm{Na}-? \\
\text { Serum } \mathrm{K}-? \\
\text { Dehydration-none }\end{array}$ & $\begin{array}{l}146 \mathrm{mEq} . \\
6.0 \mathrm{mEq} . \\
\text { Severe }\end{array}$ \\
\hline 9 G.M. & $\begin{array}{r}210 / 12 \\
\text { years }\end{array}$ & "E" & & & & & 6 & $<1 \ddagger$ & & $\begin{array}{l}\text { D.A.-C.E. } \\
\text { D.A.-Ch.E. }\end{array}$ & $\begin{array}{l}\text { Serum } \mathrm{Na}, 134 \mathrm{mEq} . \\
\text { Serum K, } 5.3 \mathrm{mEq} \text {. } \\
\text { Urinary } \mathrm{Na}, 96 \\
\text { Dehydration-none }\end{array}$ & $\begin{array}{l}118 \mathrm{mEq} . \\
6.4 \mathrm{MEq} . \\
10 \\
\text { Severe }\end{array}$ \\
\hline 10 B.O. & 3 years & “E” & $<2$ & & & & & $2 \ddagger$ & & D.A.-C.E. & $\begin{array}{l}\text { Serum } \mathrm{Na}, 153 \mathrm{mEq} . \\
\text { Serum } \mathrm{K}, 6.7 \mathrm{mEq} . \\
\text { Body wt., } 14.1 \mathrm{Kg} . \\
\text { Urinary } \mathrm{Na}-\text { ? } \\
\text { Dehydration-none }\end{array}$ & $\begin{array}{l}138 \mathrm{mEq} . \\
5.6 \mathrm{mEq} . \\
13.0 \mathrm{Kg} . \\
22 \mathrm{mEq} . \\
\text { Moderate } \\
\text { Not in cl. } \\
\text { crisis }\end{array}$ \\
\hline 11 L.W. & 9 years & $\mathbf{0}$ & $\begin{array}{l}2 \\
1\end{array}$ & $<1$ & $\begin{array}{l}4 \\
2\end{array}$ & & $\begin{array}{l}8 \\
4\end{array}$ & $\begin{array}{l}9 \\
5 \ddagger\end{array}$ & & $\begin{array}{c}\text { D.A.-C.E. } \\
\text { I.D. }\end{array}$ & $\begin{array}{l}\text { Serum } \mathrm{Na}, 141 \mathrm{mEq} . \\
\text { Serum } \mathrm{K}, 4.8 \mathrm{mEq} \text {. } \\
\text { See Figure } 4 \mathrm{~A}\end{array}$ & $\begin{array}{l}140 \mathrm{mEq} . \\
5.2 \mathrm{mEq} \text {. }\end{array}$ \\
\hline
\end{tabular}

* During the period of salt restriction (Group B) sodium intake was limited to less than $9 \mathrm{mEq}$. per day. The following symbols are used: "E", cortisone (15 to $37.5 \mathrm{mg}$. per day); D.A., dog assay; C.E., crude extract; Ch.E., chromatographed extract ; I.D., isotope derivative assay, $\ddagger$ crisis day $; \dagger$ same patient. 


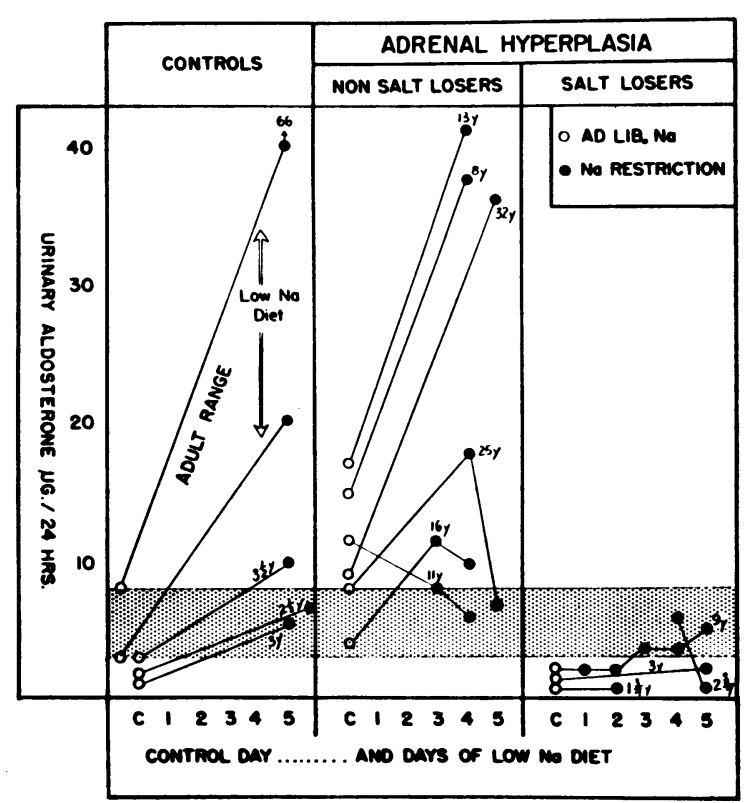

Fig. 3. The Response in Aldosterone Excretion to a 9 mEQ. Restricted Sodium Diet by Normal Individuals, Patients with Virilizing Adrenal Hyperplasia Without Associated Salt Losing Symptoms, and Patients with Salt Losing Form of Virilizing Adrenal Hyperplasia

The symbol $y$ indicates age in years. The shaded area represents the normal adult range of aldosterone excretion when adults are on an ad lib. salt intake.

made. This had no apparent suppressive or enhancing effect on aldosterone excretion.

Six of these patients were subjected to a low sodium diet for four or five days. With one exception this caused a significant increase of aldosterone excretion (Figure 3). As in normal individuals, sodium was conserved by diminution of urinary excretion, serum electrolytes remained stable, and body weight diminished gradually (Figure 4B).

\section{$V$. Aldosterone excretion in children with adrenal} hyperplasia who previously had salt losing symptoms (Table IV)

Studies were carried out on four children, one and three-fourths to three years of age who had previously had salt losing symptoms requiring desoxycorticosterone acetate (DCA) pellet implanatation or 9 alpha-fluoro-hydrocortisone (Figure 3). At the time of the study they had required no salt retaining steroid for at least one year but were maintained on suppressive doses of cortisone with a liberal intake of salt. One of these children (E.S.) had developed an adrenal crisis with dehydration secondary to a respiratory infection at the time of the study. At this time, although dehydrated, the serum sodium was $143 \mathrm{mEq}$. per L., and serum potassium, $6.0 \mathrm{mEq}$. per $\mathrm{L}$. The other three children were quite healthy and clinically were considered to have recovered from the salt losing tendency. Treatment with cortisone was continued while they were subjected to periods of salt deprivation. One child (S.W.), one and three-fourths years, within 72 hours after initiating salt restriction had a fall of serum sodium to $124 \mathrm{mEq}$. per L., and a loss of body weight from 9,900 to $9,300 \mathrm{Gm}$. The aldosterone excretion remained less than $1 \mu \mathrm{g}$. per 24 hours, and urinary sodium excretion remained $22 \mathrm{mEq}$. per 24 hours

\section{ALOOSTERONE EXCRETION IN 9 YEAR OLD PATIENT WITH HYPERPLASIA \& SALT LOSS}

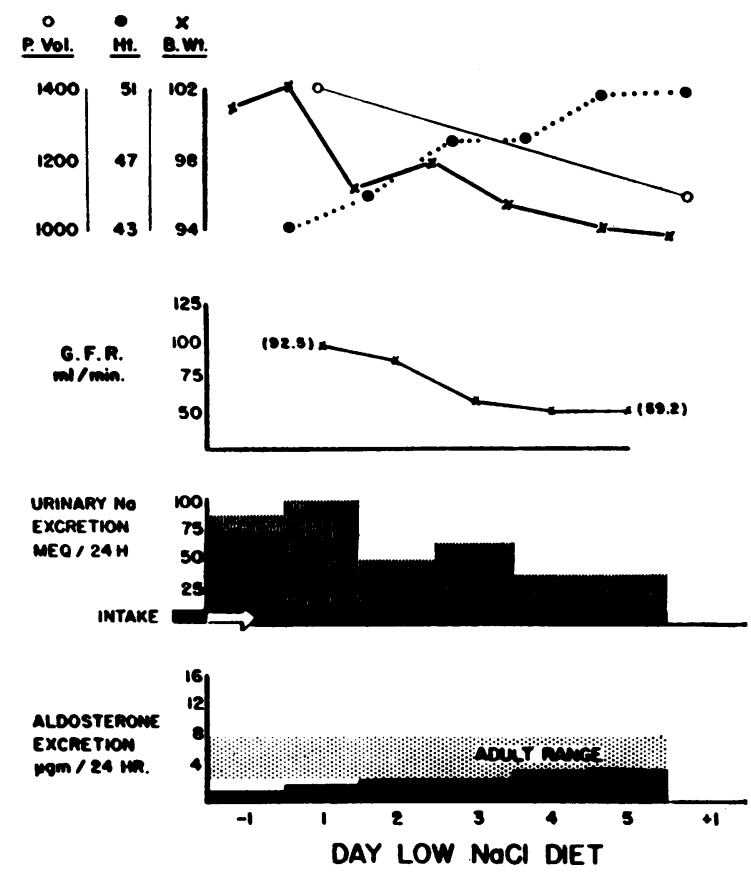

Fig. 4A. The EFfect of a 9 mEQ. Sodium Diet on Plasma Volume (P. Vol.), Hematocrit (Ht.), Body Weight (B. Wt.), Glomerular Filtration Rate (G.F.R.) and Urinary Sodium and Aldosterone Excretion in a Nine Year Old Patient with Virilizing Adrenal Hyperplasia Having a History of Associated Salt Loss

Salt retaining steroids, however, had not been required for several years. The shaded area in the lower graph represents the normal adult range of aldosterone excretion when adults are on an lib. salt intake. 

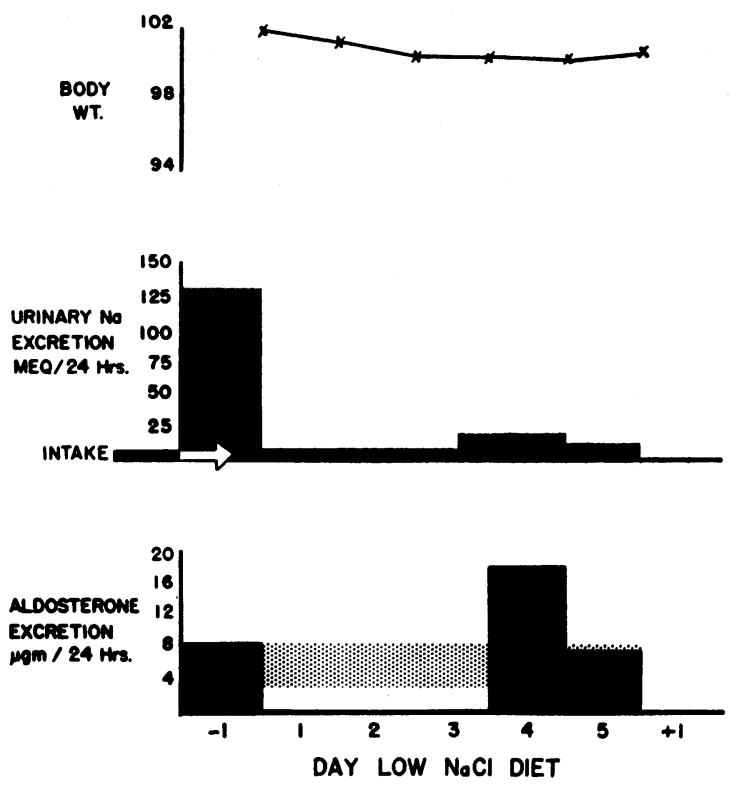

Fig. 4B. Aldosterone Excretion in an Adult Patient with Hyperplasia Without Salt Loss

The effect of a $9 \mathrm{mEq}$. sodium diet on some of the same parameters as diagrammed in Figure 4A is shown for a 32 year old patient with virilizing adrenal hyperplasia without a history of associated salt loss. The shaded area in the lower graph represents the normal adult range of aldosterone when adults are on an ad lib. salt intake.

although sodium intake was $1 \mathrm{mEq}$. and dehydration and circulatory impairment were severe. The other two infants (G.M., B.O.) also were unable to adapt to sodium deprivation with an increased output of aldosterone (Figure 3 ), and continued to lose sodium in the urine.

Further evidence that patients with salt losing adrenal hyperplasia are unable to secrete normal quantities of aldosterone was obtained by intensively studing a nine year old girl (L.W.) with the syndrome (Figure 4A). While on unrestricted sodium intake, this child had required no salt retaining steroid for several years. On a restricted sodium diet for five days her body weight decreased from 102 to 94 pounds. Simultaneously the hematocrit rose from 43 to 51 , the plasma volume fell from 1,395 to $1,135 \mathrm{ml}$., and the glomerular filtration rate fell from 92.5 to $59.2 \mathrm{ml}$. per minute. On the fifth day sodium excretion was still $43 \mathrm{mEq}$. per 24 hours indicating inability to conserve sodium. Aldosterone excretion on the fifth day remained at the low level of $5 \mu \mathrm{g}$. per 24 hours as assayed by the isotope derivative method, and $9 \mu \mathrm{g}$. as assayed by the dog assay.

\section{DISCUSSION}

Certain distinct differences in aldosterone excretion were observed between various groups studied. That these differences were not a result of using different assay methods can be appreciated by inspection of the tables. Since the two variations of bioassay gave comparable results, "sodium losing substances" were probably not present in the crude extracts or the quantities were too small to modify the results of the study.

Comparison of aldosterone excretion in children with that of adults has never been thoroughly investigated. Luetscher studied the urine of four normal children, four to eight years of age, maintained on a liberal sodium intake, and determined the aldosterone content to be approximately onehalf that of normal adults (12). Our limited studies presented in this report suggest that aldosterone excretion in childhood is proportionate to the child's size, as is true for corticosteroid excretion (13).

Aldosterone excretion of patients with virilizing adrenal hyperplasia also has never been extensively studied. The only report has been that of Prader and co-workers (6) who reported aldosterone assays on urine of six patients with virilizing adrenal hyperplasia, two without salt loss and four with this complication. One of the two individuals without salt loss excreted an increased quantity of aldosterone and the other a normal amount. Two of the four patients with salt loss excreted normal quantities of aldosterone and two excreted increased quantities. Our data confirm those presented by Prader and associates for individuals having non-salt losing, virilizing adrenal hyperplasia, but differ from theirs for individuals having the salt losing form of the disease. In our investigation none of the 11 patients with salt loss excreted elevated amounts of aldosterone. Our data suggest that aldosterone excretion by this group may, in fact, be low in comparison to normal or non-salt losing, virilizing 
adrenal hyperplasia patients of the same age. The patients with salt loss also did not respond normally to salt deprivation with increased aldosterone excretion and conservation of sodium. The discrepancy between our data and those of Prader and co-workers is not explained. Conceivably there are variations in this group of patients although all our studies have consistently suggested low aldosterone excretion in patients with the salt losing type of virilizing adrenal hyperplasia.

One might speculate that the failure of sodium deprived, salt losing patients to respond normally with increased aldosterone excretion is that hydrocortisone deficiency may prevent this normal response. That hydrocortisone does not explain the failure of these patients to increase their urinary aldosterone and conserve sodium during salt deprivation is indicated by the following considerations : 1) "Salt losers" on cortisone therapy were no better able to respond than those not receiving cortisone (Table IV) during salt deprivation, and 2) patients with hydrocortisone deficiency secondary to panhypopituitarism have been shown to retain their capacity to increase aldosterone excretion during sodium deprivation $(14,15)$.

A second consideration as to the etiology of the low levels of aldosterone excretion is the decreased glomerular filtration rate observed in L.W., and undoubtedly present in the dehydrated patients. It is unlikely that change in glomerular filtration rate accounts entirely for the low urinary levels of aldosterone as patients with other diseases in which glomerular filtration rate may be low excrete increased quantities of aldosterone $(12,16$, 17). Normal production of aldosterone, therefore, probably does not occur in these patients, even in the presence of decreased intravascular volume, which is one of the primary stimuli for aldosterone production (18). Consequently an inherent assumption in the present study is that urinary aldosterone levels reflect the rate of secretion of this hormone.

Whether some factor in addition to the limited capacity to secrete aldosterone might play a role in the salt losing form of virilizing adrenal hyperplasia remains obscure. Differences in the sodium losing tendency of these patients and of patients with Addison's disease were noted by Crigler,
Silverman and Wilkins (4). They concluded that the steroids secreted by the "abnormal adrenals" of the former group caused sodium loss either by antagonizing the action of "sodium retaining" hormone or because of a specific "sodium losing" factor. This hypothesis was based on the observation that considerably greater amounts of desoxycorticosterone were necessary to control the salt loss in untreated than in cortisone treated patients, and that corticotropin administration caused sodium diuresis. In addition, Wilkins, Klein and Lewis (3), in 1950, reported one patient who had salt losing symptomatology only secondary to adrenocorticotropic hormone (ACTH) administration. Many workers subsequently have unsuccessfully attempted to isolate a specific "sodium diuretic" steroid from the urine of patients with the salt losing type of virilizing adrenal hyperplasia.

Recently Bongiovanni and Eberlein (7) have demonstrated a more severe defect in the production of hydrocortisone in patients with the salt losing type of virilizing adrenal hyperplasia than in those without this complication. They suggest that the salt loss is related to the severity of the enzymatic defect. Since both hydrocortisone and aldosterone require hydroxylation of 21-desoxyhydrocortisone at $\mathrm{C}_{21}$, and since Bongiovanni and Eberlein (19), and Jailer, Gold, Vande Wiele and Lieberman (20) have shown that patients with virilizing adrenal hyperplasia, except those with the hypertensive type, have varying defects of hydroxylation at $\mathrm{C}_{21}$ it might be expected that the "salt losers" would be unable to excrete normal quantities of aldosterone. Our data would suggest that such is the case.

Deficiency of aldosterone in this group is not unexpected as Lewis, Klein and Wilkins (21) demonstrated the absence of the zona glomerulosa in the salt losing type of virilizing adrenal hyperplasia. Giroud, Stachenko and Piletta (22) have shown that this is the only zone of the beef adrenal that is capable of producing aldosterone, and Ayres Garrod, Tait and Tait (23) have confirmed these findings in human adrenal.

Our data suggest also that some patients with non-salt losing adrenal hyperplasia excrete greater than normal amounts of aldosterone when on un- 
restricted salt intake. If confirmed in subsequent studies this would support the hypothesis that there is a "sodium losing" factor produced by the adrenals of most patients with virilizing adrenal hyperplasia, but that compensation occurs if aldosterone production can be increased. Prader and associates (6) have been proponents of this theory.

\section{SUM MARY}

Aldosterone excretion has been measured in seven normal children, age one week to three and one-half years, and in 16 adults maintained on a normal and low salt diet. The data indicate that normal children do not excrete adult levels of aldosterone but are probably capable of responding to a low salt intake with moderately increased excretion of aldosterone.

Individuals with virilizing adrenal hyperplasia, but without salt loss, excrete normal or high levels of aldosterone, and are able to respond normally to a low sodium diet with increased aldosterone excretion and sodium conservation.

In contrast, data are presented suggesting that patients with virilizing adrenal hyperplasia with associated salt loss are unable to excrete normal quantities of aldosterone even when they are dehydrated and have diminished intravascular volume. It is therefore concluded that impaired ability to synthesize aldosterone probably contributes to the disturbed electrolyte balance characteristic of this syndrome.

\section{REFERENCES}

1. Blizzard, R. M., and Wilkins, L. Present concepts of steroid therapy in virilizing adrenal hyperplasia. Arch. intern. Med. 1957, 100, 729.

2. Darrow, D. C. Congenital adrenal cortical insufficiency with virilism. Yale J. Biol. Med. 1944, 16, 579.

3. Wilkins, L., Klein, R., and Lewis, R. A. The response to ACTH in various types of adrenal hyperplasia in Proceedings of the First Clinical ACTH Conference, J. R. Mote, Ed. Philadelphia, Blakiston, 1950, p. 184.

4. Crigler, J. F., Jr., Silverman, S. H., and Wilkins, L. Further studies on the treatment of congenital adrenal hyperplasia with cortisone. IV. Effect of cortisone and compound B in infants with disturbed electrolyte metabolism. Pediatrics 1952, 10, 397.

5. Barnett, H. L., and McNamara, H. Electrolyte balances in male infant with adrenocortical insuff- ciency and virilism. The effect of desoxycorticosterone acetate and salt therapy with special references to potassium. J. clin. Invest. 1949, 28, 1498.

6. Prader, A., Spahr, A., and Neher, R. Erhöhte Aldosteronausscheidung beim kongenitalen adrenogenitalen Syndrom. Schweiz. med. Wschr. 1955, 85, 1085.

7. Bongiovanni, A. M., and Eberlein, W. R. Defective steroidal biogenesis in congenital adrenal hyperplasia. Pediatrics 1958, 21, 661.

8. Liddle, G. W., Cornfield, J., Casper, A. G. T., and Bartter, F. C. The physiological basis for a method of assaying aldosterone in extracts of human urine. J. clin. Invest. 1955, 34, 1410.

9. Kliman, B., and Peterson, R. E. Isotope derivative assay of aldosterone in biological extracts. Fed. Proc. 1958, 17, 255.

10. Storaasli, J. P., Krieger, H., Friedell, H. L., and Holden, W. D. The use of radioactive iodinated plasma protein in the study of blood volume. Surg. Gynec. Obstet. 1950, 91, 458.

11. Miller, B. F., and Winkler, A. W. The renal excretion of endogenous creatinine in man. Comparison with exogenous creatinine and inulin. $\mathrm{J}$. clin. Invest. 1938, 17, 31.

12. Luetscher, J. A., Jr. Excretion of aldosterone in the urine of normal children and children with nephrosis in A Symposium on Adrenal Function in Infants and Children, L. I. Gardner, Ed. New York, Grune and Stratton, 1955, chap. XII.

13. Jacobsen, A. W., Koepf, G. F., Talbot, N. B., and Wilkins, L. Panel discussion: The adrenal gland in health and disease. Pediatrics 1949, 3, 515.

14. Liddle, G. W., Duncan, L. E., Jr., and Bartter, F. C. Dual mechanism regulating adrenocortical function in man. Amer. J. Med. 1956, 21, 380.

15. Coppage, W. S., Jr., and Liddle, G. W. Hypopituitarism following postpartum hemorrhage (Sheehan's Syndrome). Sth. med. J. (Bgham, Ala.) 1958, 51, 1401.

16. Deming, Q. B., and Luetscher, J. A., Jr. Bioassay of desoxycorticosterone-like material in urine. Proc. Soc. exp. Biol. (N. Y.) 1950, 73, 171.

17. McCall, M. F., and Singer, B. Studies in nephrosis: Chemical corticoids, salt-retaining factor, and effect of ACTH. J. clin. Endocr. 1953, 13, 1157.

18. Bartter, F. C., Biglieri, E. G., Pronove, P., and Delea, C. S. Effect of changes in intravascular volume on aldosterone excretion in man in International Symposium on Aldosterone, A. F. Muller, and C. M. O'Connor, Eds. London, J. and A. Churchill Ltd., 1958, 100.

19. Bongiovanni, A. M., and Eberlein, W. K. Clinical and metabolic variations in the adrenogenital syndrome. Pediatrics 1955, 16, 628.

20. Jailer, J. W., Gold, J. J., Vande Wiele, R., and Lieberman, S. 17 $\alpha$-Hydroxyprogesterone and 21- 
desoxyhydrocortisone; their metabolism and possible role in congenital adrenal virilism. J. clin. Invest. 1955, 34, 1639.

21. Lewis, R. A., Klein, R., and Wilkins, L. Congenital adrenal hyperplasia with psuedohermaphrodism and symptoms of Addison's disease. J. clin. Endocr. $1950,10,703$.

22. Giroud, C. J. P., Stachenko, J., and Piletta, P. In ritro studies of the functional zonation of the adrenal cortex and of the production of aldosterone in International Symposium on Aldosterone, A. F. Muller and C. M. O'Connor, Eds. London, J. and A. Churchill Ltd., 1958, 56.

23. Ayres, P. J., Garrod, O., Tait, S. A. S., and Tait, J. F. Primary aldosteronism (Conn's syndrome) in International Symposium on Aldosterone, A. F. Muller and C. M. O'Connor, Eds. London, J. and A. Churchill Ltd., 1958, 143. 